\title{
Tree encroachment into savannas alters soil microbiological and chemical properties facilitating forest expansion
}

\author{
Davi Rodrigo Rossatto ${ }^{1}$ Everlon Cid Rigobelo ${ }^{2}$
}

Received: 6 July 2015 / Accepted: 7 September 2015/Published online: 22 March 2016

(c) Northeast Forestry University and Springer-Verlag Berlin Heidelberg 2016

\begin{abstract}
Forests have been expanding over typical savanna sites for the past 3000 years in the Neotropics. Such invasion can produce a series of environmental modifications on typical savanna; however, it remains unclear how modifications in soil properties, caused by the encroachment of woody species, facilitate the expansion of forest ecosystems under dystrophic conditions. Here we examined chemical and microbiological changes associated with tree encroachment in oxisols of a Neotropical Savanna at Assis Ecological Station, Southeastern Brazil. We predicted that tree encroachment caused by typical forest species would cause significant changes in the chemical and microbiological properties of savanna soils. Soils were sampled at Assis Ecological Station, from savanna sites differing in tree encroachment (typical, dense and forested savanna) caused by decades of fire exclusion. We analysed vegetation leaf area index and leaf litter volume deposited in the studied plots and chemical $\mathrm{pH}$,
\end{abstract}

Project funding: This study was funded by BIOTA-FAPESP (Processo 2013/18049-6).

The online version is available at http://www.springerlink.com

Corresponding editor: Chai Ruihai

Davi Rodrigo Rossatto

drrossatto@gmail.com

1 Departamento de Biologia, Faculdade de Ciências Agrárias e Veterinárias, Univ. Estadual Paulista, UNESP, Via de Acesso Prof. Paulo Donatto Castellane S/N, Vila Industrial, Jaboticabal - SP 14884-900, Brazil

2 Departamento de Produção Vegetal, Faculdade de Ciências Agrárias e Veterinárias, Univ. Estadual Paulista, UNESP, Via de Acesso Prof. Paulo Donatto Castellane S/N, Vila Industrial, Jaboticabal - SP 14884-900, Brazil organic matter, $\mathrm{P}, \mathrm{K}, \mathrm{Ca}, \mathrm{Mg}, \mathrm{Al}, \mathrm{NO}_{3}^{-}, \mathrm{NH}_{4}^{+}$) and microbiological (microbial $\mathrm{C}$ biomass and dehydrogenase activity) properties of soils under distinct encroachment conditions. Most soil chemical properties did not change along the tree encroachment gradient; however, total P, soil organic matter, soil microbial $\mathrm{C}$ and dehydrogenase activity increased from typical savanna to forested savanna. The changes in soil organic matter and dehydrogenase activity were correlated with the values of leaf area index and litter volume along the encroachment gradient. Our results demonstrate that forest species can increase carbon and phosphorus supplies in tropical savanna soils.

Keywords Dystrophic · Encroachment · Forest - Litter · Microbiological activity

\section{Introduction}

Ecosystems are prone to change given natural processes of disturbance (Bazzaz 1990); however, in the last two decades scientists have been preoccupied about the extensive anthropogenic changes (IPCC 2007). Some of the most drastic changes occur in terrestrial environments, especially to soils through increased fertilizer inputs (Galloway et al. 2004; Sardans et al. 2012). Natural processes, such as invasion by alien species, can also create substantial changes in soil chemical properties (Ehrenfeld 2003; Vilà et al. 2011). To advance knowledge of how invasive species affect ecosystem structure and function, it is essential to consider soil fertility, especially when dealing with ecosystems naturally limited by nutrients (Sardans et al. 2012, Sugihara et al. 2014), because soil properties can drastically affects the nutritional balance of species that 
occur exclusively in dystrophic areas (Haridasan 1988; Nardoto et al. 2006; Rossatto et al. 2015).

In the Neotropics, large areas of forest and savanna ecosystems have dystrophic soils and occur side by side along their geographical distribution (Lehmann et al. 2011). In central and southeastern areas of Brazil, the typical savanna ecosystem is called the Cerrado, one of the richest tropical savannas in terms of plant species (Furley 1999; Myers et al. 2000), with a very diverse plant community of grasses, herbs and a variety of woody plants (Gottsberger and Silberbauer-Gottsberger 2006; Ribeiro and Walter 2008). Such species grow in acidic well-drained soils with a high concentration of clay and aluminum and low availability of calcium, magnesium, phosphorus and nitrogen (Furley and Ratter 1988; Haridasan 2000, 2008). Most savanna species are adapted to this low nutrient availability, and some even require high levels of aluminum to thrive (Haridasan 2008). Forest ecosystems also occur under similar acidic soils with low $\mathrm{pH}$ and nutrient concentration; however, their greater litter production and low nutrient-use efficiency leads to accumulation of organic matter at the soil surface, potentially providing better nutritional conditions for its species (Haridasan 2001; Sugihara et al. 2014; Paiva et al. 2015).

In the last 3000 years as fire frequency has significantly decreased, forests across South America have been expanding over typical savanna sites (Silva et al. 2008; Silva 2014). The consequences of this expansion into savanna have been widely studied (Hoffmann et al. 2012a, b; Murphy and Bowman 2012), and one important conclusion is that traits of forest species enable them to produce changes on the savanna environment (Hoffmann et al. 2012a). The greater crowns of forest species (Rossatto et al. 2009) shade the understory, modifying the microclimate (Hoffmann et al. 2012b). Additionally, their greater deposition of leaves in the soil surface can increase the input of nutrients in the system (Hoffmann et al. 2005; Silva et al. 2013). Despite such knowledge, nothing is known about the effect of forest invasion on the soil properties of savanna ecosystems.

Silva et al. (2013) showed that savanna oxisols do not have sufficient amount of certain nutrients (especially $\mathrm{P}$ and $\mathrm{Ca}$ ) to build a small forest biomass; however, the advance and encroachment of forest trees into savannas could provide some of the extra nutrients needed via litter deposition (more abundant in forest species), slowly moving nutrients from forests to savannas (Silva and Anand 2011; Paiva et al. 2015). This input, coupled with the fact that typical forest species have great amount of leaves in their larger canopy (Rossatto et al. 2009; Hoffmann et al. 2012a; Rossatto et al. 2013), may provide great inputs of nutrients in typical dystrophic savanna oxisols, changing its chemical and biological properties. The massive input of forest tree leaves (Paiva et al. 2015) is also likely to affect microbiological communities in soils, since greater inputs of carbon and nutrients (especially $\mathrm{N}$ and $\mathrm{P}$ ) can increase the amount of microbial resources (Bunt and Rovira 1995; Curiel Yuste et al. 2007).

In the present study, we examined the effects of tree encroachment, as forests expand into savannas, on the chemical and microbiological aspects of soil properties in the savanna ecosystem. In a typical savanna region under tree encroachment for the past 50 years (Durigan and Ratter 2006), we used the heterogeneity of tree invasion (Pinheiro and Durigan 2009) as a "natural experiment" to evaluate the effect of forest encroachment in savanna soils. We hypothesized that chemical soil properties such as $\mathrm{pH}$ and macronutrients will be elevated in forested savanna in comparison with typical savanna. This increase should be caused by the effect of high abundance of forest tree species in denser and forested savanna sites, which are likely to have a higher leaf area index (larger canopy cover), which in turn will deposit much more leaf litter and nutrients (Paiva et al. 2015). We expect also that the great input of leaf litter will increase the organic matter and thus essential resources to increase the microbial biomass and activity and select for microorganisms that are involved in organic matter decomposition.

\section{Materials and methods}

\section{Study site}

The study was done at the Assis Ecological Station (AES) in Assis Municipality, São Paulo State, Brazil $\left(22^{\circ} 35^{\prime} 51.36^{\prime \prime} \mathrm{S}, 50^{\circ} 22^{\prime} 26.68^{\prime \prime} \mathrm{W}\right)$ in October 2014 . The study site comprises a typical Neotropical savanna vegetation (regionally called Cerrado), where the climate is a transition between Cwa and Cfa according to the Köppen classification, with a dry season from May to September and a rainy season from October to April. According to the Brazilian Soil Taxonomy System (Embrapa 2006), the soil type is Latossolo Vermelho, a well-weathered, drained and deep oxisol, with high aluminum oxide content and low concentrations of available nutrients such as $\mathrm{P}, \mathrm{Mg}, \mathrm{K}$ and Ca (Juhász et al. 2006).

\section{Tree encroachment gradient}

We selected 15 border regions at AES $\left(22^{\circ} 35^{\prime} 53.47^{\prime \prime} \mathrm{S}\right.$ and $50^{\circ} 21^{\prime} 57.42^{\prime \prime} \mathrm{S}$ ) that had a gradient between typical savanna (no encroachment) and forested savanna (encroached). Following the approach used to study a forest-savanna boundary in Central Brazil (Geiger et al. 2011), we positioned a transect perpendicular to the forest edge and 
centered at the border in each of these border regions. The selection of these borders was based on field observations and on maps published by Pinheiro and Durigan (2009), who studied tree encroachment in the AES for 40 years using aerial photographs. Each transect was $165 \mathrm{~m}$ long, representing three successional stages: (a) typical savanna (TS): vegetation with a discontinuous tree layer, spread in a continuous herb-grass stratum; (b) dense savanna (DS): primarily a TS, but with a denser tree layer created from the invasion of typical forest species (Pinheiro and Durigan 2012); and (c) forested savanna (FS): previously a TS, but now primarily a continuous tree layer with a few herbaceous species and no grasses. We placed one $1 \times 1 \mathrm{~m}$ plot in the TS, one plot at the DS and one plot for FS, totaling 15 plots per each encroachment condition. To characterize the degree of tree encroachment at each studied condition, we measured the leaf area index (LAI). LAI was measured taking hemispheric photographs in each plot using a CI110-24P-ID plant canopy imager (CID Bioscience, Camas, WA, USA). The higher the LAI value, greater the degree of tree encroachment. To evaluate the quantity of litter deposited in each plot, we measured the thickness of the litter layer in each of the 45 studied plots using a precision ruler $(\mathrm{mm})$. The volume of litter deposited in each plot $\left(\mathrm{m}^{3}\right)$ was calculated as the area of the plot $\left(1 \mathrm{~m}^{2}\right)$ multiplied by the thickness of the litter layer measured with the ruler.

\section{Soil chemical and microbiological analysis}

We collected samples at the top $0-20 \mathrm{~cm}$ soil depth, to characterize the surface soil fertility of each site (TS, DS and FT) at each transect. We used one composite soil sample per plot (four subsamples per plot), totaling 15 samples per each successional condition, 45 samples in total. Just after sampling, soil subsamples were mixed and placed in plastic bags, quickly sealed and then taken to the laboratory. For chemical analysis, $\mathrm{pH}$ was determined in $\mathrm{CaCl}_{2}$ using the method of Raij et al. (1987). Soil P was determined by spectrophotometry after anion exchange resin extraction (Raij et al. 1987). Soil K, Ca, Mg and Al were determined by flame spectrophotometry (Allen et al. 1974). Basis saturation (BS) was calculated as the sum of potassium, calcium and magnesium (Embrapa 1997). Organic matter was determined after the addition of potassium dichromate-sulphuric acid to the soil samples (Sims and Harby 1971). Ammonium and nitrate levels were determined using the indophenol blue method of Keeney and Nelson (1982). $\mathrm{NO}_{3}{ }^{-}$and $\mathrm{NH}_{4}{ }^{+}$results were expressed on a dry mass basis. Chemical analysis were taken at the Soil Analysis Laboratory, in the Soils and Fertilizers Department, from the FCAV/UNESP Campus de Jaboticabal.
Microbial $\mathrm{C}$ biomass was determined according to the irradiation-extraction method (Mendonça and Matos 2005), by applying electromagnetic energy (microwaves) to the soil samples to disrupt microbial cellular membranes and release the intracellular compounds (Islam and Weil 1998). This method is optimal for microbial C determination, since it provides an instantaneous rise in soil temperature and abruptly reduces microbial activity, maximizing the release of microbial $\mathrm{C}$ biomass and minimizing the solubilization of humic substances (Islam and Weil 1998). To quantify the microbial activity in the studied soils, we determined the dehydrogenase activity, which reflects the total range of oxidative activity of soil microflora (Nannipieri et al. 1990). Dehydrogenase activity was determined according to the modified method of Casida (1977), by adding $0.06 \mathrm{~g} \mathrm{CaCO}_{3} 0.5 \mathrm{~mL}$ of $0.5 \%$ triphenil tetrazolium chloride, and $1.0 \mathrm{~mL}$ of distilled water to $3 \mathrm{~g}$ soil in test tubes. The tubes were plugged and incubated for $24 \mathrm{~h}$ at $37{ }^{\circ} \mathrm{C}$. The mixture was filtered on Whatman No. 1 filter, and the triphenyl formazan (TPF) was extracted with $5 \mathrm{~mL}$ methanol and colourimetrically determined at $485 \mathrm{~nm}$, using methanol as a control. Results were expressed as $\mu \mathrm{g} \mathrm{TPF} / \mathrm{g}$ dry soil $24 \mathrm{~h}$.

\section{Statistical analysis}

The majority of data possessed normality (KolmogorovSmirnov test, $d<0.15$ and $P>0.20$ ) and homogeneity of variances (Levene's test $F<2.00$ and $P>0.11$ ). The $\mathrm{OM}$ and $\mathrm{Mg}$ soil values were $\log _{10}$-transformed before the analysis because they lacked normality, and $\mathrm{Al}$ values were $\log _{10}$-transformed because they lacked homogeneity of variances. A univariate ANOVA was used to test for differences in tree encroachment (LAI) and litter volume of the studied areas. The post hoc Fisher's least significant difference (LSD) test was used to test for differences among treatments. A multivariate analysis of variance (MANOVA) was used to detect differences among successional conditions for chemical and microbiological aspects. Before the analysis, all data were transformed, subtracting each parameter value by the population mean and dividing by the standard deviation (Z-score transformation) (Gotelli and Ellison 2004). If a MANOVA was significant, individual univariate ANOVAs were used as post hoc tests to determine which response variables differed among conditions. The post hoc Fisher's LSD test $(\alpha=0.05)$ was used to test for differences among treatments. Linear regression was used to test for the effect of LAI variation on litter volume and microbiological parameters. The statistical procedures were carried out using Statistica Software 7.0 (Statsoft, Tulsa, OK, USA) using to all cases $\alpha=0.05$. 


\section{Results}

\section{LAI and litter volume in the tree encroachment gradient}

We found differences in the leaf area index (LAI) among the forested, dense and typical savanna areas $(F=68.073$, $P<0.001$ ), indicating distinct degrees of tree encroachment. Regions that are still typical savanna (TS), possessed LAI values close to 1 (Fig. 1a), while LAI increased to approximately 1.4 in the dense savanna (Fig. 1a) and 1.6 in the forested area (Fig. 1a). We also found significant differences $(F=17.34, P<0.001)$ in the leaf litter volume (Fig. 1b) deposited at the soil surface among the three studied areas. The amount of deposited litter was correlated $\left(r^{2}=0.412, P<0.01\right)$ with the values of LAI (Fig. 1c).

\section{Chemical and microbiological soil analysis}

Soil properties differed (MANOVA: Wilks' $=0.4770$, $F=2.76, P=0.003$ ) (Table 1; Fig. 2) along the tree encroachment gradient. All studied conditions showed very acidic soils ( $\mathrm{pH}$ around 3.8), low amounts of macronutrients such $\mathrm{K}, \mathrm{Ca}$ and $\mathrm{Mg}$ (Table 1$)$ and similar $(F=4.80$ $P=0.029$ ) contents of ammonium (Fig. 2a) and nitrite (Fig. 2b). Differences were found ( $F=4.80 P=0.029)$ to the amount of $\mathrm{P}$ (Table 1): forested and dense savanna possessed higher concentration of this element in their soils. Furthermore, forested and denser savanna plots possessed elevated dehydrogenase activity (Fig. 2c), higher organic matter (Fig. 2d) and microbial C biomass (Fig. 2e) in comparison with typical savanna sites $(F>5.00$, $P<0.05)$.

\section{Relationship between tree encroachment and soil properties}

Changes in soil traits were partially explained by changes on the degree of canopy cover of the studied conditions
(Fig. 3). We found a linear and positive relationship $\left(r^{2}=0.277, P<0.01\right)$ between leaf area index and the microbial activity (dehydrogenase activity) (Fig. 3a), and between LAI and total soil organic matter $\left(r^{2}=0.264\right.$, $P<0.01$; Fig. 3b). Forested savanna sites possessed the highest microbiological activity and the highest organic matter content.

\section{Discussion}

In accordance with our expectations, forested savanna sites had soils with higher $\mathrm{P}$ concentration, higher organic matter and elevated activity of microorganisms (evaluated by the dehydrogenase) in contrast to typical savanna sites. These results were tightly related to leaf area index, and consequently, with the amount of deposited litter. Areas with elevated canopy cover produced greater litter volumes in the studied plots, resulting in an elevated content of organic matter, which in turn promoted the elevated microorganism biomass and activity in such sites. These results provide evidence that expansion of forest species under savanna sites not only can change aspects related to the plant community structure (Hoffmann et al. 2012a) and microclimate (Hoffmann et al. 2012b), but also can provide significant changes on specific soil parameters (Paiva et al. 2015).

Differences in LAI values were expected between the different degrees of tree encroachment, since typical savanna vegetation at our study site has gone through succession, with increasing tree density and basal area (Pinheiro and Durigan 2012). The increase in tree density and basal area in such areas is mainly driven by the colonization of typical forest species, since fire has been suppressed for decades (Fensham et al. 2003; Durigan and Ratter 2006). It is well reported in the literature that forest species are able to colonize savanna environments under suppressed fire (Rossatto et al. 2009; Hoffmann et al. 2012a). Such species possess larger canopies (Archibald and Bond 2003) with more leaves, which, in comparison
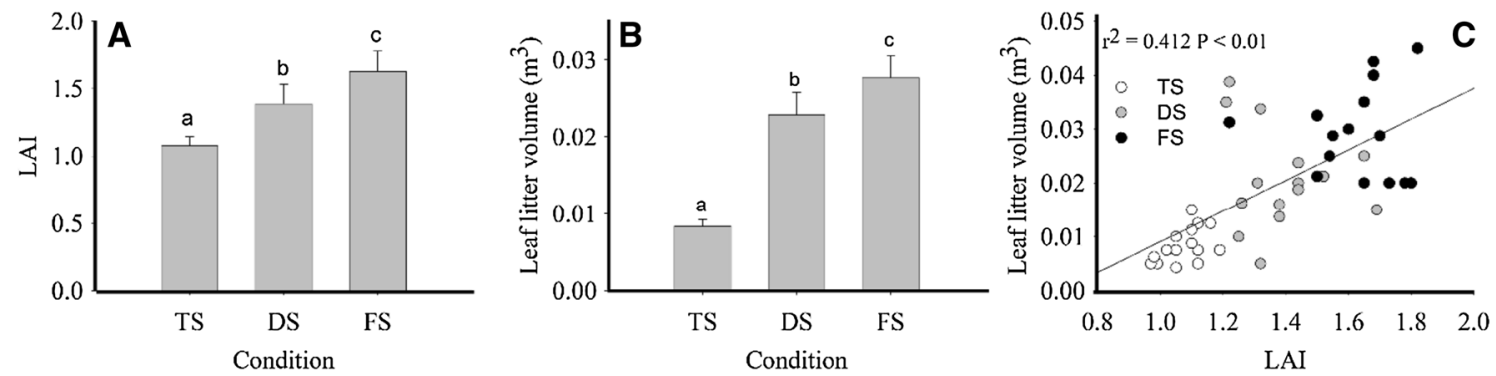

Fig. 1 Leaf area index (LAI) (a) and leaf litter volume (b) in the distinct successional savanna state. c Relationship between LAI and leaf litter volume. $T S$ typical savanna, $D S$ dense savanna, $F S$ forested savanna. Different letters indicate statistically significant differences between tree encroachment treatments according to the Fisher LSD test $(\alpha=0.05)$. Vertical bars indicate standard error of means $(n=15)$ 
Table 1 Soil chemical properties $(0-20 \mathrm{~cm}$ deep) in the sampled plots at the Assis Ecological Station, Assis, SP, Brazil. Values are means $( \pm \mathrm{SE})$ for 15 samples

\begin{tabular}{lccr}
\hline Soil properties & \multicolumn{2}{l}{ Successional stage } \\
\cline { 2 - 4 } & TS & DS & FS \\
\hline $\mathrm{pH}$ & $3.80 \pm 0.08 \mathrm{a}$ & $3.72 \pm 0.08$ & $3.74 \pm 0.05$ \\
$\mathrm{P}\left(\mathrm{mg} \mathrm{dm}^{-3}\right)$ & $3.00 \pm 0.55 \mathrm{c}$ & $3.80 \pm 0.35 \mathrm{~b}$ & $4.60 \pm 0.39 \mathrm{a}$ \\
$\mathrm{Al}\left(\mathrm{mmol}_{\mathrm{c}} \mathrm{dm}^{-3}\right)$ & $14.80 \pm 1.64 \mathrm{a}$ & $13.60 \pm 1.66 \mathrm{a}$ & $18.40 \pm 1.51 \mathrm{~b}$ \\
$\mathrm{H}+\mathrm{Al}\left(\mathrm{mmol}_{\mathrm{c}} \mathrm{dm}^{-3}\right)$ & $41.40 \pm 3.71 \mathrm{a}$ & $80.60 \pm 51.40 \mathrm{a}$ & $58.60 \pm 9.83 \mathrm{a}$ \\
$\mathrm{K}\left(\mathrm{mmol}_{\mathrm{c}} \mathrm{dm}^{-3}\right)$ & $0.66 \pm 0.41 \mathrm{a}$ & $0.54 \pm 0.5 \mathrm{a}$ & $0.70 \pm 0.12 \mathrm{a}$ \\
$\mathrm{Ca}\left(\mathrm{mmol}_{\mathrm{c}} \mathrm{dm}^{-3}\right)$ & $3.20 \pm 0.44 \mathrm{a}$ & $3.20 \pm 0.57 \mathrm{a}$ & $2.60 \pm 0.54 \mathrm{a}$ \\
$\mathrm{Mg}\left(\mathrm{mmol}_{\mathrm{c}} \mathrm{dm}^{-3}\right)$ & $1.01 \pm 0.22 \mathrm{a}$ & $1.20 \pm 0.44 \mathrm{a}$ & $1.00 \pm 0.15 \mathrm{a}$ \\
$\mathrm{BS}\left(\mathrm{mmol}_{\mathrm{c}} \mathrm{dm}^{-3}\right)$ & $4.86 \pm 0.86 \mathrm{a}$ & $4.94 \pm 0.92 \mathrm{a}$ & $4.30 \pm 0.51 \mathrm{a}$ \\
\hline
\end{tabular}

Different letters after values across a row indicate a significant difference statistical between tree encroachment according with Fisher LSD test $(\alpha=0.05)$

TS Typical savanna, $D S$ dense savanna, $F S$ forested savanna, $B S$ basis saturation
Fig. 2 Soil properties at the studied successional states in AES, Assis, SP, Brazil. a Ammonium $\left(\mathrm{NH}_{4}^{+}\right)$. b Nitrite $\left(\mathrm{NO}_{3}{ }^{-}\right)$. c Microbial activity (measured as dehydrogenase activity). d Organic matter (OM). e Microbial carbon. TS typical savanna, $D S$ dense savanna, $F S$ forested savanna. Different letters indicate statistically significant differences between tree encroachment treatments according to Fisher LSD test $(\alpha=0.05)$. Vertical bars indicate standard error of means $(n=15)$
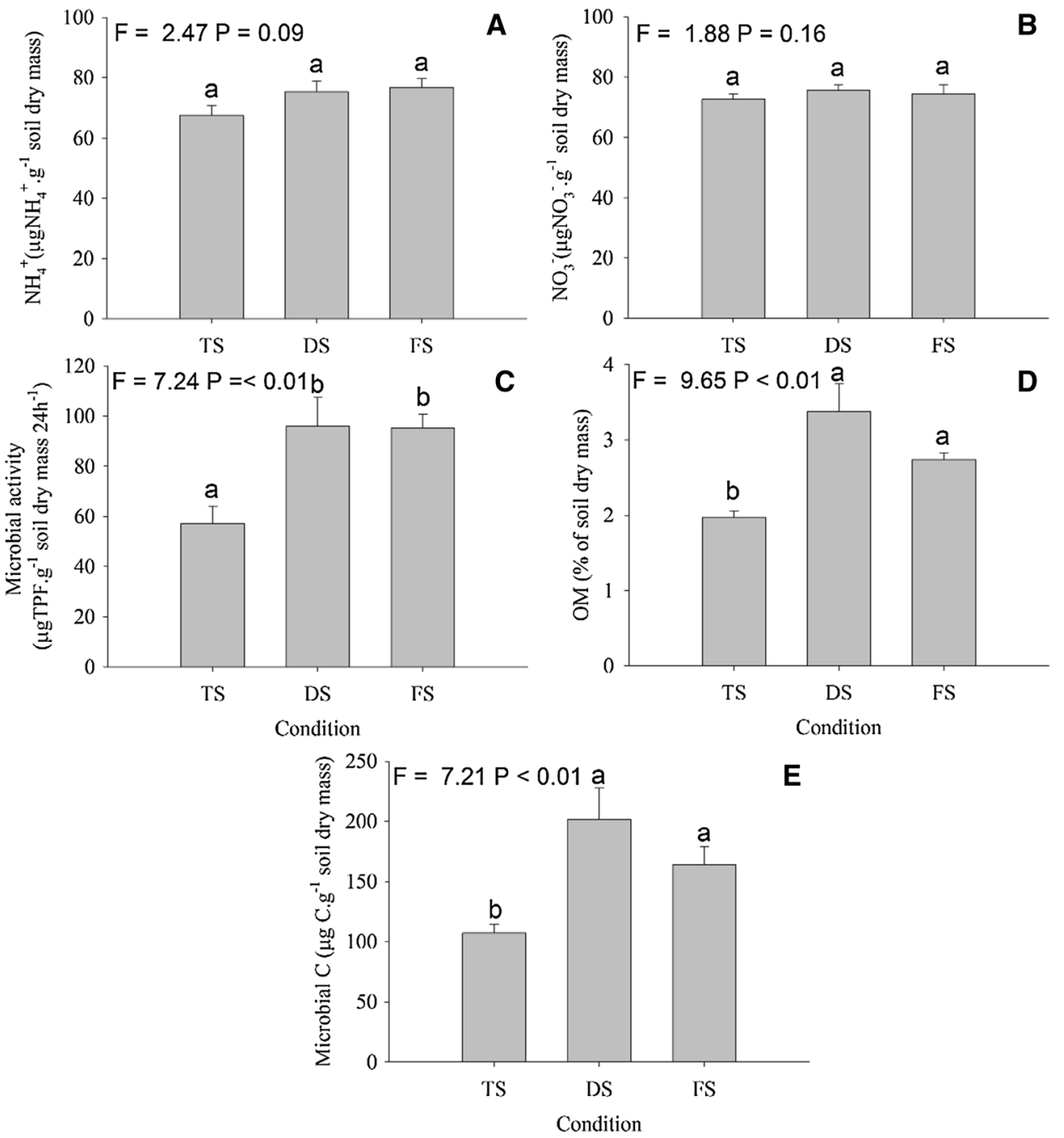

with typical savanna species, promotes an effective densification of environments where these species have increased in abundance (Rossatto et al. 2009; Hoffmann et al. 2012a, b). This specific architecture of forest tree species can also create a more humid and temperature stable environment (Hoffmann et al. 2012b). 
Fig. 3 Relationships between leaf area index (LAI) and soil properties. a LAI and microbial activity (measured as dehydrogenase activity). b LAI and soil total organic matter (OM). TS typical savanna, $D S$ dense savanna, $F S$ forested savanna
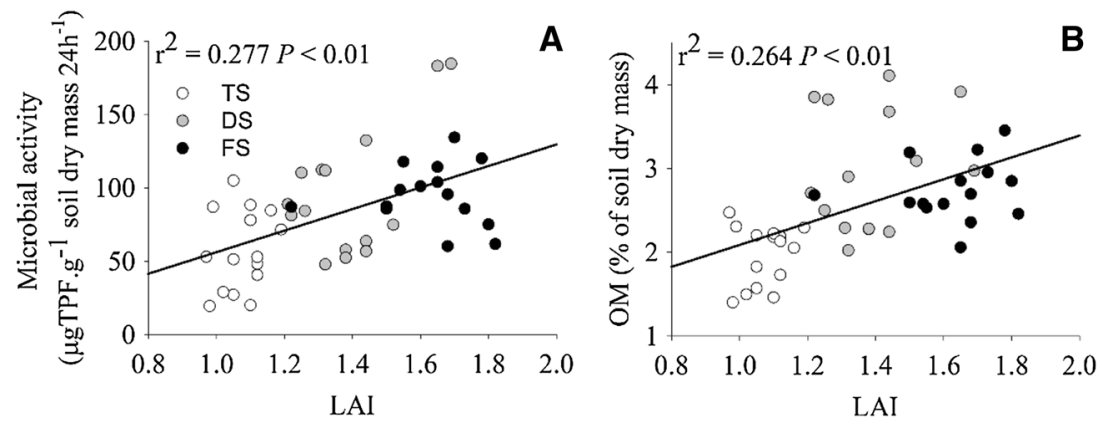

Canopy and leaf nutritional properties of forest species may explain the observed changes on soil chemical aspects (Silva et al. 2013; Sugihara et al. 2014): forest species have larger canopies and more leaves with elevated leaf nutrient concentration (especially N, P and K), in comparison with savanna species (Hoffmann et al. 2005; Silva et al. 2013; Rossatto et al. 2013). The changes found in soil P content along the encroachment gradient may be explained in this context (Hoffmann et al. 2005). Forest species have $25 \%$ more $\mathrm{P}$ in their leaves $\left(0.86 \mathrm{mg} \mathrm{g}^{-1}\right)$ than typical savanna species $\left(0.69 \mathrm{mg} \mathrm{g}^{-1}\right)$ (Silva et al. 2013), and their litter adds more P to soils than savanna litter does (Paiva et al. 2015). Consequently, the great input of a nutrient-rich litter in typical savanna soils under encroachment may increase their $\mathrm{P}$ content, which can be readily used by the soil microfauna and microflora (Lilienfein et al. 2001; Paiva et al. 2015).

The greater input of leaf litter in forested savanna plots also increased the content of soil organic matter. With more organic resources, microorganisms likely increased their number, as confirmed by the increase in microbial biomass, and their metabolism (Kanchikerimath and Singh 2001). The elevated dehydrogenase activity found in forested plots suggests higher microbial activity than in the savanna sites (Singh et al. 1989). Microbial respiration is mainly determined by temperature, water availability and chemical composition of the organic material (Nannipieri et al. 1990). This result implies that the changes in microclimate and deposition of a better quality litter by forest species (Paiva et al. 2015) acts in concert to accelerate the decomposition and nutrient cycling in these new forested systems (Curiel Yuste et al. 2007), providing more nutrients that can be used toward increasing the basal area and biomass of typical forest species (Silva et al. 2013).

Such previously reported responses may be responsible for the creation of a new stable state in which low soil fertility, low leaf litter deposition and slower decomposition rates of the savannas (Chen et al. 2008) has been replaced by rapid deposition and decomposition of leaf litter, which are mainly found in tropical forest ecosystems (Vitousek 1984; Vitousek and Sanford 1986). Many authors have considered that $\mathrm{P}$ can limit these changes because it is recycled most efficiently and can be limiting to the generation of forest biomass (Silva et al. 2013; Paiva et al. 2015). However, the typical savanna soils in São Paulo State (the area of the study) have $30 \%$ more nutrients than soils in Central Brazil (Souza et al. 2015), the site of the studies by Silva et al. (2013) and Paiva et al. (2015).

One additional important aspect of such changes in soil properties is the possible effects on the nutrition and survival of typical savanna species. Many savanna species evolved under nutrient-limiting conditions (Medina 1993) and are very efficient at internal nutrient recycling (Kozovits et al. 2007), and many are in fact dependent on elevated Al levels to complete their life cycles (Haridasan 2008). Although some species can respond to increases in $\mathrm{P}$ content and other aspects of soil fertility, increasing their productivity (Delgado et al. 2013), Haridasan (2008) found evidence that many typical savanna species cannot establish, grow and survive under elevated nutrient conditions. Jacobson et al. (2011) showed that the diversity of shrubs and herbs can also be drastically reduced by $\mathrm{P}$ fertilization. These changes in soil properties, linked with reduced light availability created by the increase in tree density and LAI values, may lead to the rapid disappearance of typical herbs and grasses found at local scales on some tropical savanna sites (Rossatto et al. 2008).

\section{Conclusions}

Here we provided evidence that the forest species invading savanna environments are able to alter soil properties, especially the $\mathrm{P}$ content. Specific traits of forest species can increase microbial biomass and their activity, changing the typical savanna soils to a distinct stable state, in which the soils have more organic matter and nutrients.

Acknowledgments We acknowledge BIOTA-FAPESP (Processo 2013/18049-6) for financial support.

\section{References}

Allen SW, Grimshaw HM, Parkinson JA, Quarmby C (1974) Chemical analysis of ecological materials. Blackwell Scientific Publications, Oxford 
Archibald S, Bond WJ (2003) Growing tall vs growing wide: tree architecture and allometry of Acacia karroo in forest, savanna, and arid environments. Oikos 102(1):3-14

Bazzaz FA (1990) The response of natural ecosystems to the rising global $\mathrm{CO}_{2}$ levels. Annu Rev Ecol Syst 21:167-196

Bunt JS, Rovira AD (1995) Microbiological studies of some subantartic soils. J Soil Sci 6:119-128

Casida LE (1977) Microbial metabolic activity in soil as measured by dehydrogenase determinations. Appl Environ Microbiol 34:630-636

Chen CR, Condron LM, Xu ZH (2008) Impacts of grassland afforestation with coniferous trees on soil phosphorus dynamics and associated microbial processes: a review. For Ecol Manag 255:396-409

Curiel Yuste J, Baldocchi DD, Gershenson A, Goldstein A, Misson L, Wong S (2007) Microbial soil respiration and its dependency on carbon inputs, soil temperature and moisture. Glob Change Biol 13(9):2018-2035

Delgado MN, Gomes MRA, Bao SN, Rossatto DR (2013) Fertilisation residues alter leaf scleromorphy in an evergreen savannah shrub (Maprounea brasiliensis, Euphorbiaceae). Aust J Bot 61:266-273

Durigan G, Ratter JA (2006) Successional changes in cerrado and cerrado/forest ecotonal vegetation in western São Paulo State, Brazil, 1962-2000. Edinb J Bot 63:119-130

Ehrenfeld JG (2003) Effects of exotic plant invasions on soil nutrient cycling processes. Ecosystems 6(6):503-523

Embrapa - Empresa Brasileira de Pesquisa Agropecuária (1997) Manual de métodos de análise de solo, 2nd edn. Centro Nacional de Pesquisa do Solo, Rio de Janeiro

Embrapa - Empresa Brasileira de Pesquisa Agropecuária (2006) Sistema Brasileira de Classificaçãod e Solos, 2nd edn. Embrapa Solos, Rio de Janeiro

Fensham RJ, Fairfax RJ, Butler DW, Bowman DMJS (2003) Effects of fire and drought in a tropical eucalypt savanna colonized by rain forest. J Biogeogr 30(9):1405-1414

Furley PA (1999) The nature and diversity of neotropical savanna vegetation with particular reference to the Brazilian cerrados. Glob Ecol Biogeogr 8(3-4):223-241

Furley PA, Ratter JA (1988) Soil resources and plant communities of the Central Brazilian cerrado and their development. J Biogeogr 15:97-108

Galloway JN, Dentener FJ, Capone DG, Boyer EW, Howarth RW, Seitzinger SP, Asner GP, Cleveland CC, Green PA, Holland EA (2004) Nitrogen cycles: past, present, and future. Biogeochemistry 70:153-226

Geiger EL, Gotsch SG, do Vale GD, Haridasan M, Franco AC, Hoffmann WA (2011) Distinct roles of savanna and forest tree species in regeneration following fire suppression in a Brazilian savanna. J Veg Sci 22:312-321

Gotelli NJ, Ellison AM (2004) A primer of ecological statistics. Sinauer Associates, Sunderland

Gottsberger G, Silberbauer-Gottsberger I (2006) Life in the cerrado: a South American tropical seasonal ecosystem. Origin, structure, dynamics and plant use, vol I. Reta Verlag, Ulm

Haridasan M (1988) Performance of miconia albicans (sw.) triana, an aluminum-accumulating species, in acidic and calcareous soils. Commun Soil Sci Plant Anal 19(7-12):1091-1103

Haridasan M (2000) Nutrição mineral das plantas nativas do Cerrado. Revista Brasileira de Fisiologia Vegetal 12:54-64

Haridasan M (2001) Nutrient cycling as a function of landscape and biotic characteristics in the cerrado of central Brazil. In: McClain ME, Martinelli LA, Richey JE (eds) Biogeochemistry of the Amazon basin and its role in a changing world. Oxford University Press, New York, pp 68-83
Haridasan M (2008) Nutritional adaptations of native plants of the cerrado biome in acid soils. Braz J Plant Physiol 20:183-195

Hoffmann WA, Franco AC, Moreira MZ, Haridasan M (2005) Specific leaf area explains differences in leaf traits between congeneric savanna and forest trees. Funct Ecol 19:932-940

Hoffmann WA, Geiger EL, Gotsch SG, Rossatto DR, Silva LCR, Lau OL, Haridasan M, Franco AC (2012a) Ecological thresholds at the savanna-forest boundary: how plant traits, resources and fire govern the distribution of tropical biomes. Ecol Lett 15:759-768

Hoffmann WA, Jaconis SY, McKinley KL, Geiger EL, Gotsch SG, Franco AC (2012b) Fuels or microclimate? Understanding the drivers of fire feedbacks at savanna-forest boundaries. Austral Ecol 37:634-643

IPCC (2007) Contribution of working group III to the fourth assessment report of the Intergovernmental Panel on Climate Change. Cambridge University Press, Cambridge

Islam KR, Weil RR (1998) A rapid microwave digestion method for colorimetric measurement of soil organic carbon. Commun Soil Sci Plant Anal 29:2269-2284

Jacobson TKB, Bustamante MMC, Kozovits AR (2011) Diversity of shrub tree layer, leaf litter decomposition and $\mathrm{N}$ release in a Brazilian cerrado under N, P and N plus $\mathrm{P}$ additions. Environ Pollut 159:2236-2242

Juhász CEP, Cursi PR, Cooper M, Oliveira TC, Rodrigues RR (2006) Soil water dynamics in a toposequence under Savanna Woodland (Cerradão) in Assis, SP, Brazil. Revista Brasileira de Ciências do Solo 30:401-412

Kanchikerimath M, Singh D (2001) Soil organic matter and biological properties after 26 years of maize-wheat-cowpea cropping as affected by manure and fertilization in a Cambisol in semiarid region of India. Agric Ecosyst Environ 86:155-162

Keeney DR, Nelson DW (1982) Nitrogen-inorganic forms. In: Page AL (ed) Methods of soil analysis, part 2. Agronomy series, 9. American Society of Agronomy, Madison, pp 643-698

Kozovits AR, Bustamante MMC, Garofalo CR, Bucci S, Franco AC, Goldstein G, Meinzer FC (2007) Nutrient resorption and patterns of litter production and decomposition in a Neotropical Savanna. Funct Ecol 21:1034-1043

Lehmann CE, Archibald SA, Hoffmann WA, Bond WJ (2011) Deciphering the distribution of the savanna biome. New Phytol 191(1):197-209

Lilienfein J, Wilcke W, Thomas R, Vilela L, Lima SC, Zech W (2001) Effects of Pinus caribaea forests on the C, N, P, and S status of Brazilian savanna Oxisols. For Ecol Manag 147:171-182

Medina E (1993) Mineral nutrition: tropical savannas. In: Progress in botany/Fortschritte der Botanik. Springer, Berlin, pp 237-253

Mendonça ES, Matos ES (2005) Matéria orgânica do solo: métodos de análises. Editora UFV, Vilosa, p 107

Murphy BP, Bowman DM (2012) What controls the distribution of tropical forest and savanna? Ecol Lett 15(7):748-758

Myers N, Mittermeier RA, Mittermeier CG, Da Fonseca GA, Kent J (2000) Biodiversity hotspots for conservation priorities. Nature 403:853-858

Nannipieri P, Greco S, Ceccanti B (1990) Ecological significance of the biological activity in soil. In: Bollag JM, Stotzky G (eds) Soil biochemistry, vol 6. Marcel Dekker Inc., New York, pp 293-355

Nardoto GB, Bustamante MMC, Pinto AS, Klink CA (2006) Nutrient use efficiency at ecosystem and species level in savanna areas of central Brazil and impacts of fire. J Trop Ecol 22:1-11

Paiva AO, Silva LCR, Haridasan M (2015) Productivity-efficiency tradeoffs in tropical gallery forest-savanna transitions: linking plant and soil processes through litter input and composition. Plant Ecol 216:775-787

Pinheiro ES, Durigan G (2009) Dinâmica espaço-temporal (1962-2006) das fitofisionomias em unidade de conservação do 
cerrado no sudeste do Brasil. Revista Brasileira de Botânica 32:441-454

Pinheiro ES, Durigan G (2012) Diferenças florísticas e estruturais entre fitofisionomias do Cerrado em Assis, SP, Brasil. Revista Árvore 36:181-193

Raij B, Quaggio JA, Cantarella H, Ferreira ME, Lopes AS, Bataglia OC (1987) Análise química de solo para fins de fertilidade. Fundação Cargill, Campinas

Ribeiro JF, Walter BMT (2008) Fitofisionomias do Bioma Cerrado. In: Sano SM, Almeida SP, Ribeiro JF (eds) Cerrado: Ecologia e flora. Planaltina, EMBRAPA Cerrados, pp 19-45

Rossatto DR, Toniato MTZ, Durigan G (2008) Flora fanerogâmica não-arbórea do cerrado na Estação Ecológica de Assis, Estado de São Paulo. Revista Brasileira de Botânica 31:409-424

Rossatto DR, Hoffmann WA, Franco AC (2009) Differences in growth patterns between co-occurring forest and savanna trees affect the forest-savanna boundary. Funct Ecol 23:689-698

Rossatto DR, Hoffmann WA, Silva LCR, Haridasan M, Sternberg LSL, Franco AC (2013) Seasonal variation in leaf traits between congeneric savanna and forest trees in Central Brazil: implications for forest expansion into savanna. Trees 27:1139-1150

Rossatto DR, Carvalho FA, Haridasan M (2015) Soil and leaf nutrient content of tree species support deciduous forests on limestone outcrops as a eutrophic ecosystem. Acta Botanica Brasílica 29:231-238

Sardans J, Rivas-Ubach A, Peñuelas J (2012) The elemental stoichiometry of aquatic and terrestrial ecosystems and its relationships with organismic lifestyle and ecosystem structure and function: a review and perspectives. Biogeochemistry 111:1-39

Silva LCR (2014) Importance of climate-driven forest-savanna biome shifts in anthropological and ecological research. Proc Natl Acad Sci USA 111(37):E3833
Silva LCR, Anand M (2011) Mechanisms of Araucaria (Atlantic) forest expansion into southern Brazilian grasslands. Ecosystems 14(8):1354-1371

Silva LCR, Sternberg L, Haridasan M, Hoffmann WA, MirallesWilhelm F, Franco AC (2008) Expansion of gallery forests into central Brazilian savannas. Glob Change Biol 14(9):2108-2118

Silva LCR, Hoffmann WA, Rossatto DR, Haridasan M, Franco AC, Horwath WR (2013) Can savannas become forests? A coupled analysis of nutrient stocks and fire thresholds in central Brazil. Plant Soil 373(1-2):829-842

Sims J, Harby VA (1971) Simplified colorimetric determination of soil organic matter. Soil Sci 112:137-141

Singh JS, Raghubanshi AS, Singh RS, Srivastava SC (1989) Microbial biomass acts as a source of plant nutrients in dry tropical forest and savanna. Nature 338:499-500

Souza MC, Franco AC, Haridasan M, Rossatto DR, Araujo JF, Morellato LPC, Habermann G (2015) The length of the dry season may be associated with leaf scleromorphism in cerrado plants. Anais da Academia Brasileira de Ciências 87(3):1-10

Sugihara S, Shibata M, Mvondo Ze AD, Araki S, Funakawa S (2014) Effect of vegetation on soil C, N, P and other minerals in Oxisols at the forest-savanna transition zone of central Africa. Soil Sci Plant Nutr 60:45-59

Vilà M, Espinar JL, Hejda M, Hulme PE, Jarošík V, Maron JL (2011) Ecological impacts of invasive alien plants: a meta-analysis of their effects on species, communities and ecosystems. Ecol Lett 14(7):702-708

Vitousek PM (1984) Litterfall, nutrient cycling, and nutrient limitation in tropical forests. Ecology 65:285-298

Vitousek PM, Sanford RLJ (1986) Nutrient cycling in moist tropical forest. Annu Rev Ecol Syst 17:137-167 